Article

\title{
Factors Influencing Food Markets in Developing Countries: An Approach to Assess Sustainability of the Food Supply in Russia
}

\author{
Vasilii Erokhin \\ School of Economics and Management, Harbin Engineering University, 145 Nantong Street, Harbin 150001, \\ China; basilic@list.ru; Tel.: +86-156-3670-9072
}

Received: 3 May 2017; Accepted: 26 July 2017; Published: 1 August 2017

\begin{abstract}
Providing sustainability of the food supply is becoming increasingly challenging in today's rapidly changing global economic environment. Food security remains a serious problem, especially in developing countries where the challenge of the sustainable food supply is exacerbated by the rapid rise in the population, limited access to food intake, vulnerability, price volatilities, protection measures imposed by the government, and other distorting influences. Russia is classified as a middle-income country that is nationally self-sufficient in its food supply. However, amid the economic recession and restrictions on foreign trade in food, many households in Russia are becoming increasingly vulnerable to food insecurity. In the case of Russia, this paper aims to assess the sustainability of the food supply, and identify the factors that affect food security. In order to establish the impact of socio-economic variables on food security at the macroeconomic level, a regression model was estimated. The study has identified the factors that influence food security in terms of agricultural production, food self-sufficiency, and foreign trade. The relationships between the regressands and corresponding regressors have been discovered, in view of alternations between positive and negative influences on the dependent variables. Additionally, a significance of the relationships has been measured. The results of the regression analysis suggest that the sustainability of the food supply in Russia is threatened by inflation and a degrading purchasing power of the population from people shifting towards cheaper products of lower quality, while exporters seek higher profits outside the country and thus create food shortages in the domestic market.
\end{abstract}

Keywords: agricultural production; export; food market; food security; food self-sufficiency; import; regression analysis

\section{Introduction}

Demand for food in the world is growing. According to the Food and Agriculture Organization of the United Nations (FAO) [1], by 2030, the global production of grain will have reached 2.1 billion tons, while the world demand for grain will have increased up to 2.7 billion tons. Although the population growth is expected to be much slower in the coming decades, the global food production needs to increase by at least $50 \%$ by 2050 to feed the growing population [2]. Countries are pursuing various policy options for increasing their agricultural outputs: expanding investment in agriculture and support of domestic producers, encouraging climate-friendly technologies, restoring degraded farmland, and improving post-harvest storage and supply chains. Still, the degradation of land, the depletion of groundwater and other natural resources, and visible impacts of climate change in shifting weather patterns have made the agricultural output more volatile [2].

Governments seek to ensure the sustainability of the food supply and increase the well-being of people, especially those with a low income. However, under a fluctuating influence of various internal and external factors, such support often backfires on the food security of a country. Food 
security is the physical, social and economic access by all people at all times to sufficient, safe, and nutritious food that meets their dietary needs and food preferences for an active and healthy life [3]. The concept of food security emerged after World War II, when reconstruction efforts created a global food regime that was increasingly sought through economic policies including trade liberalization and the opening of economic markets [4]. An increasing number of developing countries have transitioned from being net food exporters to net food importers [5]. These countries are now concerned about the sustainability of their food supply. As a counter to liberalization, they are now re-examining their strategies for achieving food self-sufficiency rather than food security, and are seeking measures to improve the sustainability of food supplies, while also protecting their domestic food markets from increasing imports [5].

The concept of food self-sufficiency is the extent to which a country can satisfy its food needs from its domestic production [6]. While food self-sufficiency is mainly focused on the provision of the optimum balance between domestic output and import [7], the FAO's approach to food security is beyond production and trade. It is based on four pillars: food availability, access, utilization, and stability [3]. In an attempt to decrease the reliance on imports, some countries reduce the availability and access to food for the population. Abundant food stocks in some countries coexist with shortages in some others, while unexpected price surges and influences of other factors push millions of people into poverty, aggravating income inequalities and threatening food security. Price instability is detrimental not only to poor countries, where deteriorating living conditions of people may raise food conflicts, but even to some developing countries. Even now, over 2 billion people in the developing part of the world spend up to $70 \%$ of their disposable income on food [2]. International trade plays a vital role in stabilizing food supplies and food prices, but importing and exporting countries also worry about the unreliability of world markets. Even high-income countries feel threatened by volatile food markets, and want to guarantee food availability and accessibility in the long run [8].

With the conditions of the volatile global food market, it is crucial to understand how any particular factors affect the sustainability of the food supply and food security. Food insecurity is influenced by various factors, among which are population growth, the availability of arable lands and water resources, and climate change [9]. As found by Nkunzimana [10], primary drivers of food insecurity in 2016 were natural disasters and extreme weather events, in particular for countries with inadequate capacities to respond to shocks. Apart from physical factors, food insecurity is influenced both by an unequal supply and by an increased demand for food on the global market [11], while availability and accessibility of food in a particular country primarily depend on the productivity of domestic agricultural producers [12]. Abu and Soom [13] conducted a factor analysis of food security in the case of Nigeria using seven factors, including the output per farm and the size of a farm and rural household, among others, and concluded that bigger households were more productive and thus more secured. Saravia-Matus et al. [8] studied economic issues of food security in low-income countries and also named low agricultural productivity among the major constraints of food availability. Anderson [14] defined food insecurity as an uncertain or limited availability of food on the domestic market or the inability to acquire adequate foods by means of domestic production.

However, the volume of domestic output does not always have a direct positive influence on the level of food security. Food insecurity also occurs due to the unavailability of food or an insufficient purchasing power [3]. Smith et al. [15] argue that the dynamics of income earning and of purchasing power are among the most important components of food insecurity. Eicher and Staatz [16], in a study on food security issues in Sub-Saharan Africa, concluded that many of the hungry in the region were malnourished not because of the low availability, but because the poor lacked the resources to gain access to the food that was available on the market. According to Eicher and Staatz [16], food security is the ability of a country to assure, on a long-term basis, that its food system provides access to a timely, reliable, and nutritionally adequate supply of food for all people. Zahrnt [17] also links food security with the cost of consumption, rather than availability, while Esturk and Ören [18] recognize income level as the most decisive variable for food security. 
Assessing food security on developing markets has to employ parameters that influence both the physical availability of food (domestic production and import) and the economic access to an adequate supply by all people (purchasing power, food inflation, distribution, etc.) [15]. Smith [19] defined two groups of factors that affect food security, i.e., supply factors (weather, production, policy incentives, stocks, and imports) and demand factors (population growth, income growth and distribution, and export revenue). As found by Ulezko and Pashina [20], there are three major groups of parameters that characterize food markets in developing countries, i.e., macroeconomic (the volume and dynamics of the Gross Domestic Product (GDP) and agricultural production, the level and dynamics of employment, and the real income of the population), trade (the volume and dynamics of the export and import of agricultural raw materials and food), and subjective (market components, including consumers and providers of agricultural commodities and food) parameters. Kolodina [21] assesses the food market potential in developing economies using such criteria as the volume of production and sales of agricultural commodities, while Kostrova [22] uses demand and supply, the price level and behavior, market infrastructure, and market regulations.

At the macro-level, the assessment of food security involves an interaction between the macroeconomics, consumption, production, stock, and trade policies of developing countries [19]. According to Saravia-Matus et al. [8], food security concerns macroeconomic issues, such as commodity price volatility, international trade, and market stability. Nkunzimana [10] states that high world prices for food have impinged on food security, severely constraining food access for people. Reeves et al. [23] agree that rising prices of food coupled with stagnating wages are a major factor driving food deprivation. In the conditions of price fluctuations, factors influencing domestic food markets become very volatile. Under this influence, the determination of food security is very vulnerable [24], especially when the market volatility is exacerbated by uncoordinated policy actions of many countries intending to ensure adequate food supplies in their domestic markets [25].

In recent years, various attempts have been made to assess influences of various factors on the production and consumption of food in developing economies, and to capture the relationship between food security and food self-sufficiency (Table 1). Regression analysis is commonly and successfully used for the investigation of the correlation between various factors of the food market and their influence on food security. However, most of the researchers have focused either on micro- or meso-levels of food security, without assessing the variables affecting food security at the macro-level. Few, if any, researchers have applied regression analysis to discover the factors that drive agricultural producers to export their products and thus influence both food self-sufficiency and food security.

This paper studies the variables affecting the sustainability of the food supply in Russia, a country that switched from the import-oriented model of food security to the import-substitution model of food self-sufficiency amid the western sanctions and economic recession. From the beginning of the 1990s until the early 2010s, Russia increased food imports, and thus secured an availability of food products on the domestic market. However, in 2014, the government declared an import-substitution policy, and banned food imports from the European Union (EU) and the United States. This study aims to investigate how the food supply has been influenced by such a pivotal change in policies. Regression analysis has never been applied to the assessment of the factors influencing Russia's food market. Ishchukova [26] implemented simple regression analysis when studying the factors affecting the Russian agricultural foreign trade, but not the market itself. Ishchukova [26] studied the relationships between seven parameters divided into five pairs, i.e., the gross agricultural and food production, the export of agricultural products, the import of agricultural products, the governmental support for agriculture, the exchange rate, world food prices, and the export prices of Russian agricultural producers. Ishchukova et al. [27] also applied simple regression analysis for assessing the relationship between the volume of agricultural production and the share of the rural population in Russia. This paper employs regression analysis to reveal the variables that affect food availability and accessibility in the import-oriented and import-substitution policy frameworks of Russia. 
Table 1. Approaches to assessing factors influencing food security in developing economies.

\begin{tabular}{|c|c|c|c|}
\hline Authors & Countries under Study & Methodology Employed & Variables Considered \\
\hline Hentschel et al. [28] & Ecuador & $\begin{array}{l}\text { Small-area } \\
\text { estimation method }\end{array}$ & $\begin{array}{l}\text { Nutrient intake, consumption of the } \\
\text { primary products, and } \\
\text { socioeconomic characteristics. }\end{array}$ \\
\hline Lekashvili [29] & Georgia & $\begin{array}{l}\text { Dynamic economic } \\
\text { rows approach }\end{array}$ & $\begin{array}{l}\text { Minimum living wage, average per } \\
\text { capita income, expenditures for } \\
\text { food, domestic food prices, share of } \\
\text { agriculture in GDP, food exports, } \\
\text { and food imports. }\end{array}$ \\
\hline Yao et al. [30] & China & Evaluation indexes system & $\begin{array}{l}\text { Food production resources, food } \\
\text { availability and stability, food } \\
\text { access, and food utilization. }\end{array}$ \\
\hline Zou and Guo [31] & China & Factor analysis & $\begin{array}{l}\text { Arable land area per capita, degree } \\
\text { of agricultural mechanization, } \\
\text { agricultural labor force, and an } \\
\text { inflation rate of grain price. }\end{array}$ \\
\hline Sharma et al. [32] & India & $\begin{array}{l}\text { Analytic hierarchy } \\
\text { process approach and } \\
\text { sensitivity analysis }\end{array}$ & $\begin{array}{l}\text { Success factors in sustainable food } \\
\text { supply chain management, and } \\
\text { food safety. }\end{array}$ \\
\hline Babu et al. [33] & $\begin{array}{l}\text { Africa, the Middle East, } \\
\text { and India }\end{array}$ & Factor analysis & $\begin{array}{l}\text { Food-related indicators } \\
\text { (staple food left in storage and } \\
\text { expenditure by the household on } \\
\text { food), assets, technology indicators, } \\
\text { market access indicators, and } \\
\text { household characteristics. }\end{array}$ \\
\hline Scafetti et al. [34] & Bangladesh & $\begin{array}{l}\text { Standard multiple } \\
\text { regression analysis }\end{array}$ & $\begin{array}{l}\text { Education and employment of } \\
\text { household members, number of } \\
\text { loans taken from microfinance } \\
\text { institutions, income, illness that } \\
\text { affects a household, health status of } \\
\text { a household, and number of } \\
\text { production sources available. }\end{array}$ \\
\hline Ali et al. [35] & Bangladesh & $\begin{array}{l}\text { Binary logistic } \\
\text { regression method }\end{array}$ & $\begin{array}{l}\text { Household size, income per } \\
\text { household, and access to credit. }\end{array}$ \\
\hline Ahungwa et al. [36] & Nigeria & $\begin{array}{l}\text { Trend analysis and multiple } \\
\text { regression analysis }\end{array}$ & $\begin{array}{l}\text { Interplay of domestic food } \\
\text { production and food importation } \\
\text { to the overall GDP. }\end{array}$ \\
\hline Oladejo [37] & Nigeria & $\begin{array}{l}\text { Cobb-Douglas } \\
\text { regression model }\end{array}$ & $\begin{array}{l}\text { Quantity of maize marketed, market } \\
\text { price for maize, cost of harvesting, } \\
\text { transport, and storage. }\end{array}$ \\
\hline Olaniyi and Ismaila [38] & Nigeria & $\begin{array}{l}\text { Binary logic } \\
\text { regression analysis }\end{array}$ & $\begin{array}{l}\text { Household size, membership of } \\
\text { social organization, and farm size. }\end{array}$ \\
\hline Maharjan and Joshi [39] & Nepal & $\begin{array}{l}\text { Binary logic } \\
\text { regression analysis }\end{array}$ & $\begin{array}{l}\text { Programs targeting small } \\
\text { landholding farms, employment, } \\
\text { household size, irrigation, } \\
\text { and participation in } \\
\text { community organizations. }\end{array}$ \\
\hline Sekhampu [40] & South Africa & $\begin{array}{l}\text { Binary logic } \\
\text { regression analysis }\end{array}$ & $\begin{array}{l}\text { Household size, household income, } \\
\text { level of education, and employment. }\end{array}$ \\
\hline Mori-Clement et al. [41] & Uzbekistan & $\begin{array}{l}\text { Autoregressive integrated } \\
\text { moving average models }\end{array}$ & $\begin{array}{l}\text { Water inflow, oil prices, market } \\
\text { exchange rate, and international } \\
\text { prices of imported commodities. }\end{array}$ \\
\hline Syrovátka and Grega [42] & Czech Republic & $\begin{array}{l}\text { Correlation and paired } \\
\text { regression analysis }\end{array}$ & $\begin{array}{l}\text { Complementary and substitution } \\
\text { relationships in consumer demand } \\
\text { for food commodities. }\end{array}$ \\
\hline
\end{tabular}

Source: author's development.

\section{Materials and Methods}

The study is guided by the hypothesis that the sustainability of the food supply would depend on the domestic agricultural output, the volume of food imports, and food exports. When taken together, the three factors determine the availability of food products on the domestic market and 
food accessibility by households. The approach employed in this study is to assess the relationships between variables of the food market aggregated in three multitudes, i.e., $M_{1}$ (domestic output), $M_{2}$ (balance between domestic output and food imports), and $M_{3}$ (food exports).

The domestic production of agricultural products and food $\left(G D P_{a g r}\right)$ is the major component of the FAO's availability pillar of food security. By aggregating the $M_{1}$ multitude, the study aims to assess how the availability of food on the domestic market is affected by the state support of agriculture, the structure of the domestic output, the economic performance of farms, and the domestic and world prices.

By aggregating the $M_{2}$ multitude, the study links availability with the FAO's access pillar, to reveal the variables that affect the volume of food imports and the share of domestically produced food in domestic consumption. The food self-sufficiency regressand (FS) is employed to capture the Russian variant of food security, which differs from common international usage [43]. The Russian government places emphasis on national vulnerability from foreign sources [44] and considers the achievement of food security to be the minimizing of foreign imports more than ensuring access to sufficient food. The $M_{2}$ multitude includes variables that allow for considering the Russian approach to food self-sufficiency and assessing the influence of the purchasing power of the population on food security. The hypothesis is that in the conditions of declining purchasing power, people tend to consume cheaper food products, which are usually of national origin. Consequently, food self-sufficiency increases, while food security, in terms of both availability and access, declines.

Multitude $M_{3}$ links food exports $\left(E_{a g r}\right)$ with the FAO's availability and access pillars. When domestic production is abundant, surpluses may be exported without any adverse effect on availability and access. In the cases of insufficient domestic production, however, exports may threaten the sustainability of the food supply by decreasing the availability of food for domestic consumption—creating shortages, and thus pushing domestic food prices up. The regressors for $M_{3}$ have been selected for the intent of revealing those factors pushing agricultural producers to export rather than to market domestically.

Multiple regression analysis employs 14 variables that reflect the food security of a country at the macro-level:

1. GDP agr -national GDP in agriculture.

2. DS—aggregated state support for domestic agricultural and food producers.

3. $E_{a g r}$-export of agricultural products and food.

4. $I_{a g r}$-import of agricultural products and food.

5. $T Q_{a g r}$ - foreign trade quota in agricultural products and food (share of foreign trade turnover in overall domestic output of food and agricultural commodities).

6. FS—food self-sufficiency.

7. $P R F$ - profitability of domestic agricultural producers (actual level, including subsidies).

8. PSP-share of small farms (personal subsidiary plots, in case of Russia) in overall agricultural production.

9. $E R-$ national currency/USD exchange rate.

10. WFPI—world food price index.

11. DEPI—export food price index of a country.

12. DFPI-domestic food price index.

13. $W_{\text {inf }}$-average annual inflation (world).

14. $D_{\text {inf }}$-average annual inflation (country).

According to the multitude approach, the variables have been grouped into three sets (Table 2). 
Table 2. Variables' sets for regression analysis.

\begin{tabular}{|c|c|c|c|c|c|}
\hline \multicolumn{2}{|c|}{$\mathbf{M}_{1}$} & \multicolumn{2}{|c|}{$\mathbf{M}_{2}$} & \multicolumn{2}{|c|}{$\mathbf{M}_{3}$} \\
\hline Regressand Y & Regressors X & Regressand Y & Regressors X & Regressand Y & Regressors X \\
\hline$G D P_{a g r}\left(\mathrm{Y}_{1}\right)$ & $\begin{array}{c}D S\left(\mathrm{X}_{1.1}\right) \\
\text { TQ } Q_{\text {agr }}\left(\mathrm{X}_{1.2}\right) \\
\operatorname{PRF}\left(\mathrm{X}_{1.3}\right) \\
\operatorname{PSP}\left(\mathrm{X}_{1.4}\right) \\
\text { WFPI }\left(\mathrm{X}_{1.5}\right) \\
\operatorname{DEPI}\left(\mathrm{X}_{1.6}\right) \\
\operatorname{DFPI}\left(\mathrm{X}_{1.7}\right)\end{array}$ & $F S\left(\mathrm{Y}_{2}\right)$ & $\begin{array}{c}G D P_{a g r}\left(\mathrm{X}_{2.1}\right) \\
D S\left(\mathrm{X}_{2.2}\right) \\
E_{a g r}\left(\mathrm{X}_{2.3}\right) \\
I_{a g r}\left(\mathrm{X}_{2.4}\right) \\
E R\left(\mathrm{X}_{2.5}\right) \\
W_{\text {inf }}\left(\mathrm{X}_{2.6}\right) \\
D_{\text {inf }}\left(\mathrm{X}_{2.7}\right) \\
\operatorname{DEPI}\left(\mathrm{X}_{2.8}\right) \\
D F P I\left(\mathrm{X}_{2.9}\right)\end{array}$ & $E_{a g r}\left(\mathrm{Y}_{3}\right)$ & $\begin{array}{c}G D P_{\text {agr }}\left(\mathrm{X}_{3.1}\right) \\
\operatorname{DS}\left(\mathrm{X}_{3.2}\right) \\
E R\left(\mathrm{X}_{3.3}\right) \\
W F P I\left(\mathrm{X}_{3.4}\right) \\
\operatorname{DEPI}\left(\mathrm{X}_{3.5}\right) \\
\operatorname{DFPI}\left(\mathrm{X}_{3.6}\right) \\
W_{\text {inf }}\left(\mathrm{X}_{3.7}\right) \\
D_{\text {inf }}\left(\mathrm{X}_{3.8}\right)\end{array}$ \\
\hline
\end{tabular}

Source: author's development.

The data have been obtained from the United Nations Conference on Trade and Development [45] $\left(G D P_{a g r}, E_{a g r}, I_{a g r}\right.$, WFPI, DEPI, $W_{\text {inf }}$, and $\left.D_{\text {inf }}\right)$, the Federal Service of State Statistics of the Russian Federation [46] (DS, FS, and PSP), and the Central Bank of the Russian Federation [47] (ER), as well as from the author's own calculations $\left(T Q_{a g r}, P R F\right.$, and $\left.D F P I\right)$ - see Table 3.

Table 3. Data for regression analysis.

\begin{tabular}{|c|c|c|c|c|c|c|c|c|c|c|c|c|c|c|}
\hline \multirow{2}{*}{ Years } & \multicolumn{14}{|c|}{ Variables } \\
\hline & $\begin{array}{c}G D P_{a g r} \\
\text { \$ Bln }\end{array}$ & $\begin{array}{c}D S \\
\text { S Bln }\end{array}$ & $\begin{array}{c}E_{a g r \prime} \\
\text { \$ Bln }\end{array}$ & $\begin{array}{c}I_{a g r} \\
\text { \$ Bln }\end{array}$ & $\begin{array}{c}T Q_{a g r} \\
\%\end{array}$ & $\begin{array}{l}F S, \\
\%\end{array}$ & $\begin{array}{c}P R F \\
\%\end{array}$ & $\begin{array}{c}P S P, \\
\%\end{array}$ & $\begin{array}{c}E R, \\
\text { RUB }\end{array}$ & $\begin{array}{l}\text { WFPI, } \\
\text { Rate }\end{array}$ & $\begin{array}{l}\text { DEPI, } \\
\text { Rate }\end{array}$ & $\begin{array}{l}\text { DFPI, } \\
\text { Rate }\end{array}$ & $\begin{array}{c}W_{\text {inf }}, \\
\%\end{array}$ & $\begin{array}{c}D_{\text {inf }}, \\
\%\end{array}$ \\
\hline 1996 & 61.5 & 4.9 & 4.5 & 16.4 & 16.9 & 83.0 & 21.8 & 48.6 & 5.1 & 120.0 & 98.0 & 23.0 & 9.0 & 47.8 \\
\hline 1997 & 55.6 & 5.4 & 4.3 & 18.0 & 20.1 & 84.0 & 21.8 & 50.2 & 5.8 & 105.0 & 65.0 & 38.0 & 5.6 & 14.8 \\
\hline 1998 & 54.9 & 2.5 & 3.7 & 14.6 & 16.7 & 83.0 & 21.8 & 57.3 & 9.7 & 95.0 & 93.0 & 55.0 & 4.4 & 27.7 \\
\hline 2001 & 34.3 & 2.3 & 4.6 & 11.4 & 23.3 & 86.0 & 11.7 & 50.2 & 29.2 & 95.0 & 72.0 & 77.0 & 3.9 & 21.5 \\
\hline 2002 & 34.1 & 1.9 & 5.8 & 12.4 & 26.7 & 87.0 & 11.7 & 53.8 & 31.3 & 100.0 & 100.0 & 100.0 & 2.9 & 15.8 \\
\hline 2003 & 36.2 & 2.2 & 7.0 & 14.5 & 29.7 & 87.0 & 11.7 & 52.6 & 30.7 & 110.0 & 80.0 & 112.0 & 3.0 & 13.7 \\
\hline 2004 & 45.5 & 2.7 & 7.9 & 16.5 & 26.8 & 87.0 & 11.7 & 47.9 & 28.8 & 115.0 & 103.0 & 117.0 & 2.9 & 10.9 \\
\hline 2005 & 54.2 & 2.8 & 10.6 & 20.6 & 28.8 & 87.0 & 16.7 & 49.3 & 28.3 & 125.0 & 120.0 & 127.0 & 3.1 & 12.7 \\
\hline 2010 & 86.4 & 8.6 & 15.8 & 37.3 & 30.7 & 86.0 & 8.3 & 48.3 & 30.4 & 230.0 & 140.0 & 203.0 & 2.8 & 6.9 \\
\hline 2011 & 115.2 & 9.1 & 21.3 & 43.9 & 28.3 & 87.0 & 11.8 & 43.7 & 29.4 & 215.0 & 145.0 & 230.0 & 3.9 & 8.4 \\
\hline 2012 & 113.8 & 9.2 & 26.0 & 41.7 & 29.7 & 89.0 & 12.1 & 43.2 & 30.9 & 205.0 & 140.0 & 220.0 & 3.1 & 5.1 \\
\hline 2013 & 116.3 & 9.5 & 25.6 & 43.8 & 29.8 & 88.0 & 13.0 & 42.6 & 32.0 & 210.0 & 150.0 & 250.0 & 2.8 & 6.8 \\
\hline 2014 & 84.2 & 8.1 & 18.9 & 36.7 & 34.8 & 89.0 & 16.2 & 41.4 & 44.5 & 200.0 & 130.0 & 270.0 & 2.8 & 7.8 \\
\hline 2015 & 95.1 & 8.2 & 16.0 & 24.3 & 30.9 & 90.0 & 16.0 & 40.5 & 64.6 & 205.0 & 135.0 & 280.0 & 2.2 & 15.5 \\
\hline
\end{tabular}

Source: author's development based on [45-47] and own calculations.

Regression analysis demonstrates a relationship between the regressands and regressors, either positive or negative. However, it is important not only to discuss the sense of the estimators, but also their significance. This paper addresses the shortcomings by proposing a scale differentiating the values of the regression coefficients in terms of the significance of particular regressors for the corresponding regressands. Simple averaging of the highest $(H)$ and the lowest $(L)$ values of the regression coefficients gives the average value $(A)$. The upper $\left(A_{t o p}\right)$ and the lower $\left(A_{\text {bottom }}\right)$ limits of $A$ are derived by simple averaging of $H$ and $A$, and $L$ and $A$, respectively. The significance of a regressor that has a positive relationship with a regressand is measured by it falling into one of five categories: the lowest, a low, an average, a high, or the highest value (Figure 1). A regressor that has a negative relationship with a regressand may have the least-negative, a low, an average, a high, or the most-negative significance. 


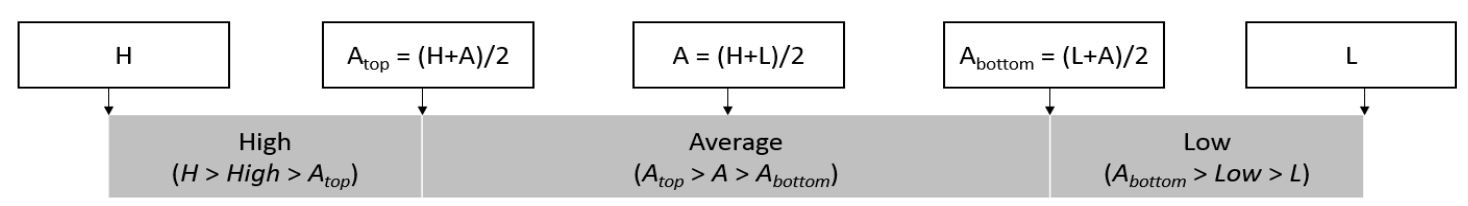

Figure 1. Scale to measure the significance of regressors. Source: author's development.

\section{Results}

\subsection{Multitude $M_{1}$}

$R^{2}$ measures the proportion of the variation that is explained by the variations in the independent variables. $R^{2}=0.9479$ means that $94.79 \%$ of the variation was explained. The adjusted $R^{2}$ measures the proportion of the variance (not the variation) that is explained by the variations in the regressors. An adjusted $R^{2}=0.9176$ means that $91.76 \%$ of the variance was explained by the regression. The F-statistic $(F=31.2075)$ was more than the critical value at a given level of significance, which also confirms the statistical significance of the regression.

The profitability of domestic agricultural producers $(P R F)$ had the highest positive significance for the volume of agricultural output $\left(G D P_{a g r}\right)$ - the increase in economic performance of agricultural producers by 1 unit resulted in an increase of the agricultural output by 316.859 units. The share of foreign trade turnover in the overall domestic output $\left(T Q_{a g r}\right)$ had the most negative significance for the agricultural output-the increase in the share of imports on the domestic market by 1 unit decreased the agricultural output by 1753.373 units (Table 4).

Table 4. Results of the regression analysis for $\mathrm{M}_{1}$.

\begin{tabular}{cccc}
\hline Variable & Coefficient & Relationship & Significance \\
\hline Y $_{1}$-intercept & $50,910.851$ & & \\
$D S$ & 6.144 & Positive & The lowest positive \\
$T Q_{a g r}$ & -1753.373 & Negative & The most negative \\
$P R F$ & 316.859 & Positive & The highest positive \\
$P S P$ & -284.492 & Negative & Low negative \\
$W F P I$ & -68.374 & Negative & The least negative \\
$D E P I$ & 222.632 & Positive & Average positive \\
$D F P I$ & 168.690 & Positive & Average positive \\
\hline
\end{tabular}

Source: author's development. Regression equation: $\mathrm{Y}_{1}=50910.851+6.144 \mathrm{X}_{1.1}-1753.373 \mathrm{X}_{1.2}+316.859 \mathrm{X}_{1.3}$ $-284.492 \mathrm{X}_{1.4}-68.374 \mathrm{X}_{1.5}+222.632 \mathrm{X}_{1.6}+168.690 \mathrm{X}_{1.7}$.

\subsection{Multitude $\mathrm{M}_{2}$}

$R^{2}=0.8680$ means that $86.80 \%$ of the variation was explained. An adjusted $R^{2}=0.7492$ demonstrates that $74.92 \%$ of the variance was explained by the regression. $F=7.3061$ was greater than the critical value at a given level of significance, which means the regression was deemed significant for $\mathrm{M}_{2}$.

Average annual inflation $\left(W_{\text {inf }}\right)$ had the highest positive significance for food self-sufficiency (FS) - the increase in the level of food inflation in the world by 1 unit pushed the food self-sufficiency up by 1.035337 units. Domestic food inflation $\left(D_{\text {inf }}\right)$, on the contrary, decreased the food self-sufficiency of a country by 0.077381 units per each unit of inflation (Table 5). 
Table 5. Results of the regression analysis for $\mathrm{M}_{2}$.

\begin{tabular}{cccc}
\hline Variable & Coefficient & Relationship & Significance \\
\hline $\mathrm{Y}_{2}$-intercept & 81.660899 & & \\
GDP agr & -0.000098 & Negative & The least negative \\
$D S$ & 0.000001 & Positive & The lowest positive \\
$E_{\text {agr }}$ & 0.000251 & Positive & Low positive \\
$I_{\text {agr }}$ & -0.000255 & Negative & Low negative \\
$E R$ & 0.054895 & Positive & Low positive \\
$W_{\text {inf }}$ & 1.035337 & Positive & The highest positive \\
$D_{\text {inf }}$ & -0.077381 & Negative & The most negative \\
$D E P I$ & -0.025403 & Negative & Average negative \\
$D F P I$ & 0.043132 & Positive & Low positive \\
\hline
\end{tabular}

Source: author's development. Regression equation: $\mathrm{Y}_{2}=81.660899-0.000098 \mathrm{X}_{2.1}+0.000001 \mathrm{X}_{2.2}+0.000251 \mathrm{X}_{2.3}$ $-0.000255 \mathrm{X}_{2.4}+0.054895 \mathrm{X}_{2.5}+1.035337 \mathrm{X}_{2.6}-0.077381 \mathrm{X}_{2.7}-0.025403 \mathrm{X}_{2.8}+0.043132 \mathrm{X}_{2.9}$.

\subsection{Multitude $M_{3}$}

$R^{2}$ was the highest among the three multitudes; $97.33 \%$ of the variation was explained by independent variables included in the model. The proportion of the variance (adjusted $R^{2}$ ) explained by the variations in the regressors was $95.39 \%$. The high value of $F=50.2023$ confirms the statistical significance of the regression for $\mathrm{M}_{3}$.

Food exports $\left(E_{a g r}\right)$ was positively influenced by the exchange rate $(E R)$-the increase in the exchange rate by 1 unit led to an increase in the value of food exports by 177.309 units. Food inflation in the world was the most negative factor-the value of food exports decreased by 60.227 units per each unit increase of food inflation (Table 6).

Table 6. Results of the regression analysis for $\mathrm{M}_{3}$.

\begin{tabular}{cccc}
\hline Variable & Coefficient & Relationship & Significance \\
\hline Y $_{3}$-intercept & -9851.349 & & \\
GDP agr & 0.207 & Positive & The lowest positive \\
$D S$ & -0.312 & Negative & The least negative \\
$E R$ & 177.309 & Positive & The highest positive \\
$W F P I$ & -1.480 & Negative & Low negative \\
$D E P I$ & 31.263 & Positive & Low positive \\
$D F P I$ & 15.147 & Positive & Low positive \\
$W_{\text {inf }}$ & -60.227 & Negative & The most negative \\
$D_{\text {inf }}$ & 3.203 & Positive & Low positive \\
\hline
\end{tabular}

Source: author's development. Regression equation: $\mathrm{Y}_{3}=(-9851.349)+0.207 \mathrm{X}_{3.1}-0.312 \mathrm{X}_{3.2}+177.309 \mathrm{X}_{3.3}$ $-1.480 X_{3.4}+31.263 X_{3.5}+15.147 X_{3.6}-60.227 X_{3.7}+3.203 X_{3.8}$.

\section{Discussion}

After the collapse of the Union of Soviet Socialist Republics (USSR) in 1991, and a set of liberal economic and land reforms of the 1990s, agricultural production experienced an essential reorganization in terms of the structure of the output. This was caused by the fall of domestic output $\left(G D P_{a g r}\right)$, the growth of import deliveries $\left(I_{a g r}\right)$, a shortage of effective demand, and the outflow of the labor force from agriculture. As long as market reforms in Russian agriculture assumed broad privatization, the domestic state support (DS) was essentially decreased, while the reorganization of land relations increased the share of small-scale personal subsidiary plots (PSP) in agricultural output, and thus raised a lot of pending questions and uncertainties; this took its toll on the effectiveness of agricultural production [48].

The relationship between domestic support and agricultural output in the $\mathrm{M}_{1}$ multitude demonstrates little impact of $D S$ on $G D P_{a g r}$. The low significance is due to the shortage of support. State 
aid has always been very low in Russia, especially during the turbulent transition period of the 1990s and then during the early 2000s. Amid the economic recession Russia has been experiencing since 2013, the government continues to cut support for domestic agricultural producers. However, the regression analysis shows a direct positive relationship between the profitability of agricultural producers and the agricultural output, and a strong positive significance of $P R F$ for $G D P_{a g r}$. Consequently, to improve the availability of food on the domestic market and increase the sustainability of the food supply, it is necessary to support the incomes of agricultural producers rather than decrease the volume of state aid.

In terms of the sustainability of the food supply, state support has to be provided to small and medium-sized agricultural producers (SMEs). In Russia, SMEs have a big share in the overall agricultural output (over $40 \%$ in 2015), but the proportion of small farms and private subsidiary plots in aggregated agricultural production (PSP) has a negative impact on $G D P_{a g r}$ - the increase in the share of small and medium farmers in the structure of agricultural production decreases the overall output. A negative relationship is because SMEs are less productive in terms of physical output, compared to mega-farms of the post-Soviet type, because of the economy of scale. Support of SMEs will improve their performance in terms of higher yields and more productive agricultural animals, and will therefore increase the availability of food on the market.

Apart from state support and the performance of farmers, the food supply in Russia is influenced by world food prices and domestic food inflation. According to Petronevich and Kondrashov [49] and Erokhin et al. [50], there is a non-symmetrical relationship between the world's and Russia's food prices. During the declining of world prices, domestic food prices decline at a slower pace, while for some commodity groups, domestic prices do not change at all. The regression analysis demonstrates the oppositely directed relationships between food prices in Russia and the world and all three regressands. Although the price index of Russian food producers tracked the global trend closely from the beginning of the 2000s until 2008-2009, the global financial recession and the crisis in Russia consequential of it opened a gap between the world food price index (WFPI) and the domestic food price index (DFPI). In the face of geopolitical difficulties regarding Crimea and Eastern Ukraine, in which Russia was involved in food counter-sanctions against the EU, the United States, and a number of the developed countries, this gap increased yet more.

Besides the relationship between export-oriented and import-substitution agricultural production, the structure and dynamics of the Russian food market are affected by price policies. After the collapse of the USSR, prices for all production factors grew at a quicker pace compared to prices for agricultural commodities and food. Agriculture in Russia suffered from the rapid growth of prices for fuel and lubricants, electric power, transportation and the storage of agricultural commodities. As a result, the essential disparity between the prices for agricultural products and the prices for other commodities rose, while the profitability of agricultural producers ( $P R F)$ was one of the lowest among the industries of the Russian economy.

Instability of the external environment also asserted a negative influence over agricultural production. Inflation $\left(D_{\text {inf }}\right)$ was maintained within the $10-20 \%$ corridor only after 2002, whereas in 1999, the year of crisis, the inflation rate went up to $84.4 \%$ [26].

Since the 1980s, Russia has been the net importer of food and agricultural products. During the 1970s and 1980s, the USSR expanded its livestock sector with the help of state subsidies. The growing demand for feed grain generated massive imports [51], particularly meat, dairy products, vegetables, and fruits [52]. Despite the high negative significance of $T Q_{a g r}$ for agricultural output, the ratio between foreign trade in food and agricultural products $\left(I_{a g r}+E_{a g r}\right)$ and $G D P_{a g r}$ remained high. In 2015, under the conditions of western sanctions against Russia and its retaliatory ban on food imports, the openness of Russia's food market to the global competition decreased. The import of food and agricultural products to Russia was $\$ 24.3$ billion in 2015 , which was lower by $33.7 \%$ in comparison with 2014 , but the foreign trade balance was still negative. According to the Analytical Center at the Government of the Russian Federation, in 2015, Russia achieved its ever-highest level of food self-sufficiency 
(FS), but despite that, there was a tremendous decrease in consumption [53]. Total food expenses of the population have been plunging since 2013, which means that people cut down consumption or reorient themselves to cheaper and less nutrient-rich foodstuffs as inflation $\left(D_{\text {inf }}\right)$ goes up and the rising RUB/USD exchange rate (ER) prevents people from access to imported foods.

Regression analysis shows that $G D P_{a g r}$ has a negative influence on FS. This may appear strange if we consider $F S$ in terms of availability, as a bigger output means there is a greater availability of food on the domestic market. However, if we look at FS from the point of view of access, such a relationship between these two parameters in the case of Russia confirms our previous reasoning on the difference between understanding food security as a share of domestically-produced food in domestic consumption and a combination of physical and economic access to sufficient and nutritious food. According to Wegren [54], Smutka et al. [55], and Spoor et al. [56], achieving food self-sufficiency in Russia is a political issue, which is not stipulated by any objective economic reasons. In Russia, where achieving food security is interpreted as increasing domestic food production to the level of food self-sufficiency, it makes no sense to raise the degree of food self-sufficiency. The prime postulate of the food security concept is physical and economic access to sufficient and nutritious food, rather than the ratio between domestically produced and imported food in consumption [57]. Under the conditions of the drop in the living standards of the population, the physical availability of food does not evolve into economic access. Formally, the share of domestically produced food on the market may reach the established level of self-sufficiency, but in reality, people cannot afford to purchase increasingly expensive food products themselves. The result is that consumption either shifts towards cheaper products of lower quality or cuts down.

Russia's case demonstrates that the achievement of a high level of food self-sufficiency does not mean a country's domestic food market is secure, in terms of both the availability of food and the access to it by all people. Even more, shrinking the domestic market forces agricultural producers to seek higher profits outside the country. The volume of food exports $\left(E_{a g r}\right)$ is influenced in a positive manner by the exchange rate $(E R)$ and the average annual inflation $\left(D_{i n f}\right)$. Both these factors have priority over domestic support and encourage producers to export, thus creating a deficit on the domestic market and threatening the sustainability of the food supply.

\section{Conclusions}

The purpose of this paper has been to discover the variables that affect the sustainability of the food supply in Russia. The study has attempted to develop an approach for the analysis of the relationship between the food supply and the domestic agricultural output, the volume of food imports, and food exports. It has been demonstrated that the expansion of agricultural output is hindered by a low profitability and financial instability of agricultural producers, a lower output of SMEs in comparison with mega-farms, and inadequate domestic support of agriculture. Food self-sufficiency grows, but food security is threatened, as food imports have become more expensive and less competitive on the Russian market because of the depreciation of the ruble. Due to the economic downturn and decreasing financial support from the government, Russian farmers are not able to expand production facilities and increase output. Apart from the devaluation of the ruble, access to food is also challenged by a decreasing purchasing power of the population, higher inflation, and import restrictions imposed by the government. In view of the growing world prices, many agricultural producers decided to export and earn revenues in foreign currencies, rather than trying to distribute on the shrinking domestic market amid the rising inflation and falling ruble. As a result, in 2016, Russia became one of the leading food exporters worldwide.

The study has identified the variables that influence the food supply and food security in terms of agricultural production, food consumption, and trade in food and agricultural products. The relationships between the regressands and corresponding regressors have been discovered, in view of alternations between positive and negative influences on the dependent variables under changing circumstances. Additionally, a significance of the relationships has been measured. 
The study has emphasized the difference between Russian and international approaches to achieving a sustainable food supply and establishing food security. Treating food security as increasing the domestic food production to the level of food self-sufficiency, the Russian government pursues minimizing foreign imports more so than ensuring access to sufficient food. In the case of Russia, it has been demonstrated that a high level of food self-sufficiency is caused not by an increase in domestic output, but by a decrease in consumption, which is a grave threat to food security. In such conditions, the government should support the domestic production of food and increase the purchasing power of the population, develop an effective demand on the domestic market, prevent agricultural producers from exporting, and create opportunities for exporters to gain their revenues on the domestic market. As the regression analysis involved the factors that influence both the availability of food products on the domestic market and their accessibility to households, it can be implemented to other developing countries to identify and assess the factors that influence food security and transform state policies accordingly.

Acknowledgments: The paper was supported by Harbin Engineering University, China (research project HEUCFJ170901) by the provision of funds to cover the costs to publish in open access.

Conflicts of Interest: The author declares no conflict of interest.

\section{References}

1. Food and Agriculture Organization of the United Nations. Food and Agriculture Data. Available online: http:/ / faostat.fao.org/beta/en/\#home (accessed on 1 May 2017).

2. Erokhin, V. Establishing Food Security and Alternatives to International Trade in Emerging Economies; IGI Global: Hershey, PA, USA, 2017.

3. Food and Agriculture Organisation of the United Nations. Food, Nutrition, and Agriculture; Food and Agriculture Organisation of the United Nations: Rome, Italy, 1992.

4. Schanbacher, W.D. The Politics of Food: The Global Conflict between Food Security and Food Sovereignty; Praeger Security International: Santa Barbara, CA, USA, 2010.

5. Valdés, A.; Foster, W. Net Food-Importing Developing Countries: Who They Are, and Policy Options for Global Price Volatility; International Centre for Trade and Sustainable Development: Geneva, Switzerland, 2012.

6. Food and Agriculture Organisation of the United Nations. Implications of Economic Policy for Food Security: A Training Manual. Available online: http://www.fao.org/docrep/004/x3936e/x3936e03.htm (accessed on 16 June 2017).

7. Meskhia, I.E. Food Security Problems in Post-Soviet Georgia. Ann. Agric. Sci. 2016, 14, 46-51. [CrossRef]

8. Saravia-Matus, S.; Gomez y Paloma, S.; Mary, S. Economics of food security: selected issues. Bio-Based Appl. Econ. 2012, 1, 65-80.

9. Premanandh, J. Factor affecting food security and contribution of modern technologies in food sustainability. J. Sci. Food Agric. 2011, 91, 2707-2714. [CrossRef] [PubMed]

10. Nkunzimana, T. Global Report on Food Crises 2017; Food Security Information Network: Rome, Italy, 2017.

11. Schiller, S.; Kasperczyk, N. Fostering Synergies between Biodiversity Conservation and Food Security; Goethe University Frankfurt: Frankfurt am Main, Germany, 2010.

12. Tiwari, P.C.; Joshi, B. Natural and socio-economic factors affecting food security in the Himalayas. Food Secur. 2012, 4, 195-207. [CrossRef]

13. Abu, G.A.; Soom, A. Analysis of factors affecting food security in rural and urban farming households of Benue state, Nigeria. Int. J. Food Agric. Econ. 2016, 4, 55-68.

14. Anderson, S.A. Core indicators of nutritional state for difficult-to-sample populations. J. Nutr. 1990, 120, 1557-1600.

15. Smith, L.C.; El Obeid, A.E.; Jensen, H.H. The geography and causes of food insecurity in developing countries. Agric. Econ. 2000, 22, 199-215. [CrossRef]

16. Eicher, C.K.; Staatz, J.M. Food security policy in sub-Saharan Africa. In Proceedings of the XIXth Conference of the International Association of Agricultural Economists, Malaga, Spain, 25 August-5 September 1985; IAAE: Milwaukee, WI, USA, 1985. 
17. Zahrnt, V. Food Security and the EU's Common Agricultural Policy: Facts against Fears. Available online: http:/ / www.ecipe.org/app/uploads/2014/12/food-security-and-the-eus-common-agriculturalpolicy-facts-against-fears.pdf (accessed on 6 March 2017).

18. Esturk, O.; Ören, M.N. Impact of household socio-economic factors on food security: Case of Adana. Pak. J. Nutr. 2013, 13, 1-6. [CrossRef]

19. Smith, M.E. World Food Security. The Effect of U.S. Farm Policy; United States Department of Agriculture: Washington, WA, USA, 1990.

20. Ulezko, A.; Pashina, L. Market of Food Resources in the Food Security System of the Far East; Voronezh State Agricultural University: Voronezh, Russia, 2014.

21. Kolodina, N. Criteria of the food market potential evaluation. Bull. Orenbg. State Agrar. Univ. 2013, 1, 157-159.

22. Kostrova, Y. Analysis of Food Market of Russia; Saint-Petersburg University of Management and Economics: Saint Petersburg, Russia, 2014.

23. Reeves, A.; Loopstra, R.; Stuckler, D. The growing disconnect between food prices and wages in Europe: Cross-national analysis of food deprivation and welfare regimes in twenty-one EU countries, 2004-2012. Public Health Nutr. 2017, 20, 1414-1422. [CrossRef] [PubMed]

24. Solaroli, L. Assessing food security in selected mediterranean countries. In Proceedings of the International ASRDLF Conference 2015, Montpellier, France, 7-9 July 2015; ASRDLF: Paris, France, 2015.

25. Restuccia, D.; Spizzirri, U.G.; Puoci, F.; Parisi, O.I.; Cirillo, G.; Vinci, G.; Picci, N. Food security: A global problem. In Advances in Food Science and Technology; Visakh, P.M., Sabu, T., Iturriaga, L.B., Ribotta, P.D., Eds.; John Wiley and Sons Ltd. and Scrivener Publishing: New York, NY, USA, 2013; pp. 19-102.

26. Ishchukova, N. The Position of the Russian Federation in the International Market of Agricultural and Foodstuff Products; Czech University of Life Sciences: Prague, Czech Republic, 2013.

27. Ishchukova, N.; Smutka, L.; Steininger, M. Russian agricultural sector development and its impact on the rural population. In Proceedings of the 23rd International Scientific Conference “Agrarian Perspectives XXIII. The Community-Led Rural Development", Prague, Czech Republic, 16 September 2014; Czech University of Life Sciences: Prague, Czech Republic, 2014.

28. Hentschel, J.; Lanjouw, J.O.; Lanjouw, P.; Poggi, J. Combining census and survey data to trace spatial dimensions of poverty: A case study of ecuador. World Bank Econ. Rev. 2000, 14, 147-165. [CrossRef]

29. Lekashvili, E. Food security policy in Georgia. In Proceedings of the Conference of the Italian Association of Agricultural and Applied Economics (AIEAA), Trento, Italy, 4-5 June 2012; AIEAA: Rome, Italy, 2012.

30. Yao, C.; Teng, Y.; Huang, L. Evaluation index system construction and empirical analysis on food security in China. Trans. Chin. Soc. Agric. Eng. 2015, 31, 1-10.

31. Zou, J.; Guo, S. China's food security evaluation based on factor analysis. Am. J. Ind. Bus. Manag. 2015, 5, 447-456. [CrossRef]

32. Sharma, Y.K.; Mangla, S.K.; Patil, P.P.; Uniyal, S. Analysis of success factors in sustainable food supply chain management using AHP approach. In Proceedings of the 11th Uttarakhand State Science and Technology Congress 2016-2017, Dehradaun, India, 2-4 March 2017; Uttarakhand State Council for Science and Technology: Dehradaun, India, 2017.

33. Babu, S.C.; Gajanan, S.N.; Sanyal, P. Impact of market access on food security-Application of factor analysis. In Food Security, Poverty and Nutrition Policy Analysis; Babu, S.C., Gajanan, S.N., Sanyal, P., Eds.; Academic Press: New York, NY, USA, 2014; pp. 139-175.

34. Scafetti, F.; Lochetti, G.; Grigoletto, R.; Mazziotta, M.; De Muro, P. Measuring food security in three district of rural Bangladesh-Sathkira, Netrakona and Rajshahi: A multidimensional perspective. In Proceedings of the Conference of the European Association for Evolutionary Political Economy (EAEPE), Manchester, UK, 3-5 November 2015; EAEPE: Rome, Italy, 2015.

35. Ali, S.; Noor, M.T.; Alam, K.J. The determinants of food security among households in Rangpur city, Bangladesh: A logistic regression approach. IOSR J. Econ. Financ. 2016, 7, 51-56. [CrossRef]

36. Ahungwa, G.T.; Haruna, U.; Muktar, B.G. Food security challenges in Nigeria: A paradox of rising domestic food production and food import. Int. Lett. Nat. Sci. 2014, 13, 38-46. [CrossRef]

37. Oladejo, J.A. comparative analysis of factors influencing quantity of maize marketed among agricultural households in Oyo and Osun States, Nigeria. Int. J. Agric. Ext. Rural Dev. Stud. 2015, 1, 1-16. 
38. Olaniyi, O.A.; Ismaila, O.K. Information and Communication Technologies (ICTs) Usage and Household Food Security Status of Maize Crop Farmers in Ondo State, Nigeria: Implication for Sustainable Development. Available online: https:/ / digitalcommons.unl.edu/libphilprac/1446 (accessed on 8 April 2017).

39. Maharjan, K.L.; Joshi, N.P. Determinants of household food security in Nepal: A binary logistic regression analysis. J. Mt. Sci. 2011, 8, 403-413. [CrossRef]

40. Sekhampu, T.J. Determinants of the food security status of households receiving government grants in Kwakwatsi, South Africa. Mediterr. J. Soc. Sci. 2013, 4, 147-153.

41. Mori-Clement, Y.; Bhaduri, A.; Djanibekov, N. Food price fluctuations in Uzbekistan: Evidences from local markets in 2002-2010. In Proceedings of the EAAE 2014 Congress "Agri-Food and Rural Innovations for Healthier Societies", Ljubljana, Slovenia, 26-29 August 2014; European Association of Agricultural Economists: The Hague, The Netherlands, 2014.

42. Syrovátka, P.; Grega, L. Analysis of methodological approaches to evaluation of complementary and substitution relationships in consumer demand for food. Agric. Econ. Czech 2002, 48, 456-462.

43. Wegren, S.K.; Nikulin, A.M.; Trotsuk, I. The Russian variant of food security. Probl. Post Commun. 2016, 64, 47-62. [CrossRef]

44. Vassilieva, Y.; Smith, M.E. Russia: Doctrine of Food Security. 2008. Available online: https://apps.fas.usda. gov/gainfiles/200811/146306496.pdf (accessed on 17 June 2017).

45. United Nations Conference on Trade and Development. Statistics Database. Available online: http://unctad. org/en/Pages/Statistics.aspx (accessed on 9 April 2017).

46. Federal Service of State Statistics of the Russian Federation. Official Statistics. Available online: http://www.gks.ru/wps/wcm/connect/rosstat_main/rosstat/ru/statistics/accounts/ (accessed on 9 April 2017).

47. Central Bank of the Russian Federation. Statistics Database. Available online: http:/ /www.cbr.ru/statistics / main.asp?Prtid=dkfs (accessed on 9 April 2017).

48. Ivolga, A.; Uryadova, T. Organisational and economic challenges of effective involvement of agricultural land into civil legal turnover. Russ. Econ. Int. J. 2010, 2, 120-127.

49. Petronevich, N.; Kondrashov, M. Relationship between inflation in Russia and dynamics of world prices for food and oil. Econ. Policy 2011, 4, 128-147.

50. Erokhin, V.; Ivolga, A.; Heijman, W. Trade liberalization and state support of agriculture: Effects for developing countries. Agric. Econ. Czech 2014, 60, 524-537.

51. Liefert, W.M.; Liefert, O. Russia's economic crisis and its agricultural and food economy. Choices 2014, 30, 1-6.

52. Svatoš, M.; Smutka, L.; Ishchukova, N. The position of agriculture in the Russian federation-The last two decades development overview. Agric. Econ. Czech 2014, 60, 489-502.

53. Analytical Center at the Government of the Russian Federation. The Food Embargo: The Results of 2015; Government of the Russian Federation: Moscow, Russia, 2016.

54. Wegren, S.K. Return to Putin's Russia. Past Imperfect, Future Uncertain; Rowman \& Littlefield Publishers: Plymouth, UK, 2013.

55. Smutka, L.; Spicka, J.; Ishchukova, N.; Selby, R. Agrarian import ban and its impact on Russian and European Union agrarian trade performance. Agric. Econ. Czech 2016, 62, 493-506.

56. Spoor, M.; Mamonova, N.; Visser, O.; Nikulin, A. Food security in a sovereign state and "quiet food sovereignty" of an insecure population: The case of post-Soviet Russia. In Proceedings of the International Conference "Food Sovereignty: A Critical Dialogue", New Haven, CT, USA, 14-15 September 2013; Yale University: New Haven, CT, USA, 2013.

57. Shagaida, N.; Uzun, V. Food Security in Russia: Monitoring, Trends and Threats; Russian Presidential Academy of National Economy and Public Administration: Moscow, Russia, 2015.

(C) 2017 by the author. Licensee MDPI, Basel, Switzerland. This article is an open access article distributed under the terms and conditions of the Creative Commons Attribution (CC BY) license (http://creativecommons.org/licenses/by/4.0/). 